\title{
Using Frangenheim's Thinking Skills Framework to Improve Academic Writing Skills in Tertiary ESL Classrooms
}

\author{
Beh Min Er \\ School of Languages, Literacies and Translation, \\ Universiti Sains Malaysia, Malaysia. \\ Malini Ganapathy \\ School of Languages, Literacies and Translation, \\ Universiti Sains Malaysia, Malaysia.
}

\begin{abstract}
Malaysian undergraduates have been facing writing difficulties as a result of lacking effective guidance tools in upskilling English writing and activating thinking skills. Failing to achieve writing competency, the problems extend to the high unemployment rate among fresh graduates. This paper proposes using Frangenheim's Thinking Skills Framework (TSF) to improve university students' academic writing proficiency. 60 students were selected to undergo a 6-week quasiexperiment to investigate the effectiveness of the TSF on academic writing and focus group discussions were held to explore students' perceptions on utilizing the TSF in writing processes. The results of the study confirmed the positive effect of using the TSF in improving students' academic writing and promoting the use of Higher-Order Thinking Skills (HOTS) throughout the writing process. Findings revealed students' perceptions on the TSF: an effective guidance tool with various writing strategies, comprises clues to activate suitable thinking skills, and assists writers' idea generation and decision-making. The implications are important to tertiary stakeholders as a practical TSF is recommended as a supplementary tool to be infused in English writing syllabus to facilitate students in fulfilling the essential thinking skills and writing needs in higher education.
\end{abstract}

\section{KEYWORDS: Thinking Skills Framework, Higher-Order Thinking Skills, higher education, English academic writing}

\section{Introduction}

In the Malaysian context, English language is taught as the second language (ESL) whereby English language is as equally emphasized as the students' mother tongue (Peng, 2019). At the tertiary level, writing skills are claimed to have an important role in determining students' 
academic achievement as most assessment and examinations are conducted in the form of written assignments (Abdulkareem, 2013). Students' academic writing competence is influenced by their cognitive development as the students' mastery of critical thinking skills is one of the crucial factors which determine whether the students can produce an effective writing (Putri, 2018).

However, tertiary students are facing writing difficulties as a result of insufficient writing strategies and poor critical thinking skills (Ismail, 2011; Wang \& Zou, 2018). According to the Fresh Graduate Report 2018, the lack of linguistic skills and thinking skills has also led to the problem of low employability rate among Malaysian Fresh Graduates (JobStreet, 2018).

To ensure the students fulfil the $21^{\text {st }}$ century needs of being linguistically and innovatively proficient, Ministry of Education Malaysia (2015) has stated two important aspirations in Executive Summary of Malaysia Education Blueprint 2015-2025 (Higher Education): (1) students are equally proficient in Bahasa Melayu and English language at the operational level, and (2) students are inquisitive and innovative in applying knowledge and higher order thinking skills (HOTS) with problem-solving initiatives. Many undergraduates struggle to perform writing tasks assigned by the lecturers as these written assignments involve not only the students' comprehension of the language contexts, but also their ability to perform critical writing skills which require them to propose their own claims, analyze the content validity, justify their viewpoints and lastly, compose an effective writing with cohesive organisations and coherent language (Yasin et al., 2010). This concern requires immediate attention as it comes to a realization that the acquired English writing skills are totally insufficient for students to deal with the academic writing tasks, let alone the various writing tasks involved in their career aspects.

To date, despite the fact that researches have been conducted to explore the pedagogical strategies in teaching ESL writing, most of the studies direct the focus on primary and secondary education. There is only minimal emphasis given to overcoming students' writing difficulties at the tertiary level. Therefore, there is a need to explore a simple and practicable thinking skills framework (TSF) to provide students with adequate assistance for them to effectively and creatively utilize the language input learnt in the ESL classrooms to fulfil the writing needs (Foster \& Russell, 2002).

Taking these into consideration, the purpose of the study was to determine the effectiveness of using the Frangenheim's TSF to upskill tertiary students' academic writing. Meanwhile, the study also aimed to explore students' perceptions on using TSF in their academic writing process.

This study addresses the following research questions:

a) How did the use of TSF affect tertiary ESL students' academic writing?

b) What were the tertiary ESL students' perceptions of using TSF in learning academic writing skills?

\section{Literature review}

In the Malaysian context, tertiary students have been facing writing difficulties and it is reported that ESL students require a lot of writing practices to master the writing skills (Ismail et al., 2012). Due to the fact that writing skills are generally perceived as a complicated language skill, it has resulted in the problem of writing anxiety among undergraduates in Malaysia (Lau \& Rahmat, 2014; Rahim et al., 2016). Writing anxiety refers to the psychological effects triggered by students' 
negative feelings, such as tension, nervousness and stress, when they are assigned with a writing task (Al_Sawalha \& Chow, 2012). The writing anxiety among tertiary students was caused by many reasons, including the lack of creativity, insufficient vocabulary knowledge and low motivation in writing (Kirmizi \& Kirmizi, 2015). This situation is worsened when English language has become the mandatory pass subject at different educational levels, as emphasized in the Malaysian educational blueprints.

\section{Theoretical Framework of the study}

This study was grounded on the conceptual framework which integrated the theories of the revised Bloom's Taxonomy (2001) and the Cognitive Process Theory of Writing (1981).

The original Bloom's Taxonomy was developed by Benjamin Bloom in year 1956, along with a team of educational psychologists. It is a classification system of six levels for the cognitive skills and educational objectives at all levels (Bloom et al., 1956). Measurable task verbs are used to help educators define nebulous terms related to measuring students' learning outcomes in cognitive domain such as "internalize" and "comprehend". In the later year, Bloom's Taxonomy was revised by Anderson et al. (2001) to incorporate new insights about pedagogies on children cognitive development.

The revised Bloom's Taxonomy retained six levels of thinking skills which include three lower order thinking skills (LOTS) and three higher order thinking skills (HOTS). The LOTS comprise remembering, understanding, and applying whereas the HOTS include analysing, evaluating and creating (Anderson et al., 2001). To simplify the use of Bloom's Taxonomy, Frangenheim (2006) proposed a thinking skills framework (Figure 1) which integrates the measurable task verbs, relevant icons and thinking tools to serve as a guideline for teachers and students to master thinking skills and language skills simultaneously.

Other than that, the Cognitive Process Theory of Writing developed by Flower and Hayes (1981) is a model used to monitor the writers' cognitive processes during a composition, particularly a written work. While using this model, the students are allowed to take control over their own writing and given opportunities to think like writers and make the "writers" decisions and choices" (Flower \& Hayes, 1981, p. 377). Therefore, linguistic accuracy is no longer prioritized and exclusive attention is given to the mental processes instead (Selvaraj \& Aziz, 2019).

Four main points are highlighted by Flower and Hayes (1981) in this model:

- The writers are involved in making decisions and choices throughout the writing processes of planning the writing, converting thoughts to verbal and reviewing the writing.

- The stages of writing have no clear cut whereby the processes, namely pre-writing, drafting, giving feedback, revising, editing and publishing, are embedded into one another when necessary.

- Writing is a goal-oriented process which requires the writers to have clear set of goals when they write.

- Writing goals are not permanent and they change as more input is gained. 


\begin{tabular}{|c|c|c|c|c|c|c|}
\hline \multirow[t]{4}{*}{  } & \multicolumn{2}{|c|}{$\begin{array}{c}\text { 1. Thinking Skills \&t Task Verbs } \\
\text { The Task 'WHY' }\end{array}$} & \multicolumn{2}{|c|}{$\begin{array}{l}\text { 2. Bloom's Six Thinking Levels } \\
\text { The Broad 'WHY' }\end{array}$} & $\begin{array}{l}\text { 3. Sentence Starters } \\
\text { The 'WHAT' }\end{array}$ & \multirow{2}{*}{$\begin{array}{l}\text { 4. Thinking Tools } \\
\text { The 'HOW' } \\
\text { 1:4:Publish:Circle:Refine } \\
\text { FRESH } \\
\text { Pros:Cons:Improve } \\
\text { Real Problem-Solution } \\
1 \text { \& } 2 \\
\text { Word/Image Association } \\
\text { Y Chart, Split Y Chart }\end{array}$} \\
\hline & $\begin{array}{l}\text { Create } \\
\text { Elaborate } \\
\text { Extrapolate } \\
\text { Invent } \\
\text { Forecast } \\
\text { Formulate }\end{array}$ & $\begin{array}{l}\text { Generate } \\
\text { Hypothesise } \\
\text { Modify } \\
\text { Organise } \\
\text { Plan } \\
\text { Propose }\end{array}$ & & $\begin{array}{c}\text { Acting like } \\
\text { an inventor, } \\
\text { experiencing } \\
\text { 'WOW light } \\
\text { bulb' moments } \\
\text { for new } \\
\text { products, ideas } \\
\text { or processes }\end{array}$ & $\begin{array}{l}\text { Formulate a set of criteria to judge... } \\
\text { Compose a song, jingle or rap to... } \\
\text { Plan an argument to persuade people to... } \\
\text { Generate key questions for... } \\
\text { Create a role play/experiment to... } \\
\text { Modify an existing project studied so that... } \\
\text { Organise a personal action plan to... }\end{array}$ & \\
\hline & $\begin{array}{l}\text { Argue } \\
\text { (for/against) } \\
\text { Assess } \\
\text { Conclude } \\
\text { Decide } \\
\text { Determine } \\
\text { Judge }\end{array}$ & $\begin{array}{l}\text { Justify } \\
\text { Prioritise } \\
\text { Rate } \\
\text { Recommend } \\
\text { Select } \\
\text { Verify }\end{array}$ & & $\begin{array}{l}\text { Acting like } \\
\text { the Scales of } \\
\text { Justice } \\
\text { to 'weigh up' } \\
\text { the evidence to } \\
\text { make and } \\
\text { justify a } \\
\text { decision } \\
\text { based on the } \\
\text { Analysis data }\end{array}$ & $\begin{array}{l}\text { Determine to what extent... } \\
\text { Decide which of the two...would be } \\
\text { better for... } \\
\text { Justify the decision of... } \\
\text { Judge which is more effective, A or B. } \\
\text { Evaluate the effectiveness of... } \\
\text { Select which is the best option...or... } \\
\text { Rank the following from...to most... }\end{array}$ & $\begin{array}{l}\text { Court Case } \\
\text { Decision-Making Matrix } \\
\text { Extended PCQ } \\
\text { Extent Barometer } \\
\text { Extent Barometer with } \\
\text { Perspectives } \\
\text { Tournament Prioritising } \\
\text { Y Chart }\end{array}$ \\
\hline & $\begin{array}{l}\text { Argue (about) } \\
\text { Compare } \\
\text { Complex } \\
\text { Summary } \\
\text { Contrast } \\
\text { Differentiate }\end{array}$ & $\begin{array}{l}\text { Discuss } \\
\text { (in depth) } \\
\text { Distinguish } \\
\text { Explore } \\
\text { Investigate } \\
\text { Separate }\end{array}$ & & $\begin{array}{l}\text { Acting like a } \\
\text { Microscope to } \\
\text { identify } \\
\text { the component } \\
\text { parts of an } \\
\text { issue, situation } \\
\text { or object }\end{array}$ & $\begin{array}{l}\text { Examine...from at least } 4 \text { perspectives... } \\
\text { Discuss the similarities and differences of... } \\
\text { Investigate all factors that could } \\
\text { influence...in... } \\
\text { Explain how parts interact in... } \\
\text { Explore research on the issue of...in order } \\
\text { to gain a deeper understanding of... } \\
\text { Compare the pros and cons of... }\end{array}$ & $\begin{array}{l}\text { Double Bubble Map } \\
\text { Icon Prompt } \\
\text { KWL, KWHL } \\
\text { PCQ, Extended PCQ } \\
\text { S.W.O.T. Analysis } \\
\text { T Chart } \\
\text { Y Chart }\end{array}$ \\
\hline & $\begin{array}{l}\text { Arrange } \\
\text { Calculate } \\
\text { Compile } \\
\text { Complete } \\
\text { Construct } \\
\text { Demonstrate }\end{array}$ & $\begin{array}{l}\text { Extrapolate } \\
\text { Illustrate } \\
\text { Practise } \\
\text { Show } \\
\text { Solve } \\
\text { Use }\end{array}$ & & $\begin{array}{l}\text { Acting like a } \\
\text { Formula, to } \\
\text { apply new } \\
\text { skills, rules and } \\
\text { concepts } \\
\text { to related and } \\
\text { new situations }\end{array}$ & $\begin{array}{l}\text { Apply previously learnt knowledge } \\
\text { to construct... } \\
\text { Interview a group of people to identify... } \\
\text { Compile } 4 \text { questions based on your } \\
\text { knowledge of... } \\
\text { Write a letter to the editor pointing out... } \\
\text { Construct a flow chart for... } \\
\text { Manipulate a spreadsheet to answer 'what if... } \\
\text { Show/demonstrate how to... }\end{array}$ & $\begin{array}{l}\text { Predict:Observe:Explain } \\
\text { (POE) } \\
\text { Silent Card Shuffle }\end{array}$ \\
\hline$\frac{n}{2}$ & $\begin{array}{l}\text { Comprehend } \\
\text { Describe } \\
\text { Explain } \\
\text { Interpret } \\
\text { Outline }\end{array}$ & $\begin{array}{l}\text { Paraphrase } \\
\text { Recognise } \\
\text { Summary (basic) } \\
\text { Translate } \\
\text { Understand }\end{array}$ & $\underbrace{\underbrace{C}_{C}}_{\text {UNDERSTAND }}$ & $\begin{array}{l}\text { Acting like an } \\
\text { AHA! Bubble, } \\
\text { showing } \\
\text { understanding } \\
\text { of words, } \\
\text { concepts, cause } \\
\text { and effect and } \\
\text { 'reasons for' }\end{array}$ & $\begin{array}{l}\text { Explain how...has impacted on... } \\
\text { Describe in clear logical steps... } \\
\text { Use a...metaphor to help others understand... } \\
\text { Paraphrase in your own words... } \\
\text { Using words, pictures and icons, explain } \\
\text { what you know about... } \\
\text { Give reasons for... }\end{array}$ & $\begin{array}{l}\text { Cause-Effect } \\
\text { Concept Maps } \\
\text { Metaphor } \\
\text { Multiple Intelligence } \\
\text { Model } \\
\text { Silent Card Shuffle } \\
\text { Six Icon Summary }\end{array}$ \\
\hline & $\begin{array}{l}\text { Define } \\
\text { Find } \\
\text { Label } \\
\text { List } \\
\text { Locate } \\
\text { Memorise }\end{array}$ & $\begin{array}{l}\text { Name } \\
\text { Quote } \\
\text { Remember } \\
\text { Retell } \\
\text { State }\end{array}$ & REMEMBER & $\begin{array}{l}\text { Acting like an } \\
\text { Information } \\
\text { Desk to recall } \\
\text { information, } \\
\text { facts and data }\end{array}$ & $\begin{array}{l}\text { Make an A-Z list of... } \\
\text { Name all the... } \\
\text { Describe what happened at... } \\
\text { Repeat what...said about... } \\
\text { What is...(facts/definition etc.)? } \\
\text { Quote } 10 \text { facts about... } \\
\text { List the ways that you are like... }\end{array}$ & $\begin{array}{l}\text { Alpha Ladder } \\
\text { KWL } \\
\text { Silent Card Shuffle }\end{array}$ \\
\hline & \multicolumn{3}{|c|}{$\begin{array}{l}\text { 5. Co-operative and Collaborative Strategies } \\
\text { The Group 'HOW' }\end{array}$} & \multicolumn{3}{|c|}{$\begin{array}{l}\text { 6. Howard Gardner's Multiple Intelligence Model } \\
\text { The 'WHO' }\end{array}$} \\
\hline & $\begin{array}{l}\text { - 1:4:P:C:R } \\
\text { - Court Case } \\
\text { - Doughnut } \\
\text { - Hot Potato } \\
\text { - Human Cont }\end{array}$ & $\begin{array}{l}\text { - Jigsaw } \\
\text { - Pairs and } \\
\text { - Round R } \\
\text { - Silent Ca } \\
\text { m - Think, Pa }\end{array}$ & $\begin{array}{l}\text { Stimulus RAS Alert } \\
\text { obin (Silent and Noisy) } \\
\text { ard Shuffle } \\
\text { ir, Share }\end{array}$ & $\begin{array}{l}\text { - Verbal L } \\
\text { - Logical } \\
\text { - Visual/S } \\
\text { - Body/Ki }\end{array}$ & $\begin{array}{l}\text { Linguistic (Word Smart) } \\
\text { Mathematical (Number Smart) } \\
\text { spatial (Picture Smart) } \\
\text { inesthetic (Body Smart) }\end{array}$ & $\begin{array}{l}\text { ythmic (Music Smart) } \\
\text { al (People Smart) } \\
\text { al (Self Smart) } \\
\text { (Seeing Connections } \\
\text { al World) }\end{array}$ \\
\hline
\end{tabular}

Figure 1. Frangenheim's Thinking Skills Framework (Frangenheim, 2006) 
As the Frangenheim's TSF is a revised and extended version of the Bloom's Taxonomy, relevant past studies on Bloom's Taxonomy are reviewed to gather insights on how it is integrated in the ESL classrooms. First of all, it is evident in the study of Ganapathy and Kaur (2014) that using Frangenheim's TSF in the secondary ESL writing contexts is helpful to students in terms of idea generation and problem solving. It is also reported that the students are motivated to learn and employ this tool when it comes to evaluating ideas and constructing ideas based on the topic given by the teacher. The findings of the study reflect an existing research gap in introducing this TSF to the tertiary ESL writing contexts.

In another study, Moseley et al. (2005) reviewed and evaluated a total of 35 thinking frameworks and taxonomies with the aim to determine the effective framework for lifelong learning. From the findings, it is concluded that Bloom's Taxonomy is a constructive and practicable thinking framework to be used in classifying learning objectives for students at any age and with any level of ability. Regarding the effectiveness of Bloom's Taxonomy in academic writing, Korzh (2017) stated that Bloom's Taxonomy is useful in expanding students' English academic writing and reading skills and clearly presenting the expectations of the thinking skills and written tasks to the students.

Not only that, Sham (2016) has proven that students can perform better in writing tasks after they were taught with the critical thinking skills. Bloom's Taxonomy is also recommended to be included in the ESL writing courses due to its effectiveness in expanding students' ability to produce creative writing (Sham, 2016). This finding also concurs with Nevid et al. (2017) findings whereby the researchers concluded that writing tasks should be designed and assigned with the use of Bloom Taxonomy as it helps the students foster writing skills and cognitive skills simultaneously.

\section{Method}

Mixed-method research design was used to conduct the study under two phases. This research design enables the researchers to explain the quantitative data collected first by using the qualitative data collected afterwards (Creswell, 2014). The first phase was conducted with the quasi-experimental pre-test and post-test design participated by a total of 60 students to collect the quantitative data. The purpose of the first-phase collection was to determine the effectiveness of the Frangenheim's TSF in improving students' writing performance. After the participants took the pre-test, the experimental group underwent an intervention program (Figure 2) for six weeks in which they were taught to write an academic writing with the use of TSF, followed by the posttest taken by all participants. Then, the second phase of data collection took place in which it involved four focus group discussions, with each consisted of 6 experimental participants. The purpose of the discussions was to gather the experimental participants' perceptions in using the TSF to learn how to write academic writing.

\section{Participants}

The participants were 60 Malaysian undergraduate students from a private university in Ipoh who were taking the course named Academic Writing. They participated in the quasi-experiment and 
they were divided into experimental and control group with 30 of them in each group. After that, 24 experimental participants took part in the focus group discussions.

This study used a multistage sampling method. First, purposive sampling method was used to decide the sample size for the whole study with the inclusion criteria of: (1) the student is a Malaysian; (2) he/she had completed his or her registration under the course of Academic Writing. Next, random sampling method was used whereby the sample size of 60 students were equally and randomly divided into two groups, namely experimental group and control group. Lastly, purposive sampling method was once again used to decide the participants for the focus group discussions with the following inclusion criteria: (1) the student was the experimental participant; (2) he/she had participated in all sessions of the intervention.

\section{The Instrument}

There were two research instruments used in this study which were the pre-test and post-test question, as well as the question guide used in the focus group discussions. To increase the content validity of the test, the researcher adapted the writing topic from the past study conducted by Özdemir (2018). Content validity assesses whether the item in a test measures what it intends to measure (Creswell, 2014). To produce valid results on students' argumentative writing performance, this writing topic, entitled "Whether social media socializes or isolates people?" (Özdemir, 2018, p. 115) was adapted as the test questions in the quasi-experiment. Besides, the question guide was adapted from the past studies (Al Badi, 2015; Ganapathy \& Kaur, 2014) as these past studies are relevant to writing difficulties and using the Frangenheim's TSF to teach ESL writing.

\section{Interventions}

As mentioned, the experimental group took part in an intervention program which consisted of six sessions of teaching in which the participants were taught with academic writing skills by integrating the use of Frangenheim's TSF (Figure 1) throughout the whole intervention. In each intervention, they were given relevant writing tasks to practice their thinking skills at the expected levels. They had to complete the assigned writing tasks every week before the next intervention. The lesson plans were adapted from Ganapathy and Kaur (2014). The Frangenheim's TSF poster (Figure 1) was used as a guideline to design the HOTS lessons to teach academic writing by considering all six levels of Bloom's Taxonomy which covers both LOTS (i.e. remember, understand, apply) and HOTS (i.e. analyse, evaluate and design). 


\begin{tabular}{|c|c|}
\hline Task Sequence & Learning Outcomes in Bloom's Taxonomy \\
\hline $\begin{array}{l}\text { Students are given a copy of the TSF poster for their } \\
\text { reference. Students are given facts and knowledge } \\
\text { regarding the elements of an argumentative essay. } \\
\text { Students are told to act like an Information Desk. } \\
\text { Students were then required to answer 'WHAT' } \\
\text { questions on the elements of an argumentative essay } \\
\text { by recalling the knowledge and matching the } \\
\text { elements to the correct definitions. }\end{array}$ & $\begin{array}{l}\text { Remember: Acting like an Information Desk to recall } \\
\text { the relevant facts and knowledge taught by the teacher } \\
\text { and existing knowledge based on past experience if } \\
\text { applicable. } \\
\text { Students are expected to list the components of an } \\
\text { effective essay and match the elements of an } \\
\text { argumentative essay to the correct definitions. }\end{array}$ \\
\hline $\begin{array}{l}\text { Students are involved in a discussion on the topic } \\
\text { regarding whether the social media, such as } \\
\text { Facebook, encourages or discourages human } \\
\text { interactions. Students were then required to answer } \\
\text { "WHY" and "HOW" questions to describe the } \\
\text { reasons of using social media and explain how it may } \\
\text { affect human interactions. }\end{array}$ & $\begin{array}{l}\text { Understand: Acting like the 'AHA' bubble to show the } \\
\text { understanding of the topic and the expectations of the } \\
\text { writing tasks. } \\
\text { Students are expected to describe the reasons why } \\
\text { people use social media and explain how the effects of } \\
\text { social media on human interactions. }\end{array}$ \\
\hline $\begin{array}{l}\text { Students are instructed to construct a mind-map and } \\
\text { use it to illustrate the functions of social media based } \\
\text { on what they understand about this topic. Students } \\
\text { are allowed to apply any relevant knowledge as per } \\
\text { discussed in the previous lessons. }\end{array}$ & $\begin{array}{l}\text { Apply: Acting like a formula to apply new or relevant } \\
\text { knowledge, skills, and concepts to complete the writing } \\
\text { task. } \\
\text { Students are expected to construct and use a mind map } \\
\text { to compile and illustrate their ideas regarding the } \\
\text { functions of social media. }\end{array}$ \\
\hline $\begin{array}{l}\text { Students investigate the effects of social media on } \\
\text { human interactions from two points of view - } \\
\text { whether social media socializes people or isolates } \\
\text { people. Students discuss this topic in depth and } \\
\text { explore the different points of view by using a T- } \\
\text { chart. }\end{array}$ & $\begin{array}{l}\text { Analyse: Acting like a microscope to analyse an issue or } \\
\text { situation by identifying the component parts. } \\
\text { Students are expected to analyze the topic, discuss in } \\
\text { depth the effects of social media in terms of human } \\
\text { interactions and explore both agreeable and disagreeable } \\
\text { views with a T-chart. }\end{array}$ \\
\hline $\begin{array}{l}\text { Students evaluate the points stated in the T-chart } \\
\text { created in the previous lesson. Based on the T-chart, } \\
\text { students argue on the topic by stating their claim, } \\
\text { counterclaim and counterarguments. Students select } \\
\text { the effective arguments (points) supported with valid } \\
\text { evidence to justify their claim. }\end{array}$ & $\begin{array}{l}\text { Evaluate: Acting like the scales of justice to evaluate } \\
\text { the arguments and evidence based on the data collected } \\
\text { at the Analysis stage to justify the claim or stand. } \\
\text { Students are expected to evaluate and judge the } \\
\text { arguments, argue about a topic, and justify the claim. }\end{array}$ \\
\hline $\begin{array}{l}\text { Students plan their essays by generating more ideas } \\
\text { or elaborations based on the topic on social media. } \\
\text { Students organize the structure of the essay by using } \\
\text { an outline before composing the entire essay. } \\
\text { Students create an essay of } 500 \text { to } 600 \text { words. }\end{array}$ & $\begin{array}{l}\text { Design: Acting like an inventor by designing an output } \\
\text { based on the information gathered. } \\
\text { Students are expected to generate ideas or elaborations, } \\
\text { plan the entire essay, organize the essay structure and } \\
\text { create an argumentative writing. }\end{array}$ \\
\hline
\end{tabular}

Figure 2. Simplified lesson plan based on the writing topic "Social Media"

\section{Results}

\section{The Effectiveness of TSF in Improving Academic Writing Performance}

Both control and experimental groups took the pre-test and post-test and the scores obtained by the groups were compared and analysed to determine the effectiveness of the intervention program. The control group received the standard treatment whereas the experimental group received the experimental treatment in which the Frangenheim's TSF was used to teach academic writing in consecutive 6 lessons on a weekly basis. Table 1 displayed the mean scores obtained by the control and experimental groups in the pre-test and post-test. 
Table 1. Average Scores Obtained by Students in the Pre-test and Post-test

\begin{tabular}{ccccc}
\hline & $\begin{array}{c}\text { Number of } \\
\text { Participants }\end{array}$ & $\begin{array}{c}\text { Average Score of } \\
\text { Pre-Test }\end{array}$ & $\begin{array}{c}\text { Average Score of } \\
\text { Post-Test }\end{array}$ & $\begin{array}{c}\text { Average Score } \\
\text { Difference }\end{array}$ \\
\hline Control Group & 30 & 53.37 & 62.87 & 9.50 \\
$\begin{array}{c}\text { Experimental } \\
\text { Group }\end{array}$ & 30 & 49.64 & 70.17 & 20.54 \\
\hline
\end{tabular}

As shown in Table 1, the students in the control and experimental groups showed improvement in their post-test writing. Specifically, the average score obtained by the control group increased by 9.5 marks, from getting the average scores of 53.37 marks in the pre-test to 62.87 marks in the post-test. On the other hand, the average score obtained by the students in the experimental group increased by 20.54 marks, as the students obtained the average scores of 49.64 marks in the pretest and 70.17 marks in the post-test. The test results indicate that the experimental group, which participated in the interventions, achieved greater improvement in academic writing, as compared to the control group.

\section{Tertiary Students' Perceptions on TSF}

As from the qualitative data collected through four focus group discussions with 24 experimental participants, the perceptions of students towards the use of Frangenheim's TSF in learning academic writing were explored.

Table 2. Students' perceptions towards the effectiveness of the TSF $(\mathrm{N}=24)$

\begin{tabular}{|c|c|c|}
\hline $\begin{array}{c}\text { Effectiveness of } \\
\text { TSF }\end{array}$ & Example quote & $\begin{array}{l}\text { Frequency, } n \\
(\%)\end{array}$ \\
\hline $\begin{array}{l}\text { Delivery of task } \\
\text { instructions }\end{array}$ & $\begin{array}{l}\text { "I can clearly understand the task verbs. They made the } \\
\text { instructions clear...I was able to have clear direction to } \\
\text { think about the topic." [S4] } \\
\text { "The task verbs help me think better as they provide some } \\
\text { "clues' for me to understand the topic and complete the } \\
\text { task." [S6] } \\
\text { "They are very specific words to help me think better. For } \\
\text { example, when I see list, I know that I need to list the } \\
\text { answers in the bullet points instead of writing in } \\
\text { paragraphs. Then, when I see explain, I know I have to } \\
\text { elaborate my answers and perhaps with some examples." } \\
\text { [S14] }\end{array}$ & $24(100 \%)$ \\
\hline $\begin{array}{l}\text { Exploration of } \\
\text { topic }\end{array}$ & $\begin{array}{l}\text { "I can use the tools to explore the topics deeper and form a } \\
\text { good outline for my essay." [S3] } \\
\text { "The TSF tools help me explore the topic better because } \\
\text { they show the clear picture and the overall concept to me." } \\
\text { [S5] } \\
\text { "I can use them to expand my ideas, especially when I use } \\
\text { the mind map, because I can see how the ideas are } \\
\text { connected together." [S10] }\end{array}$ & $24(100 \%)$ \\
\hline
\end{tabular}




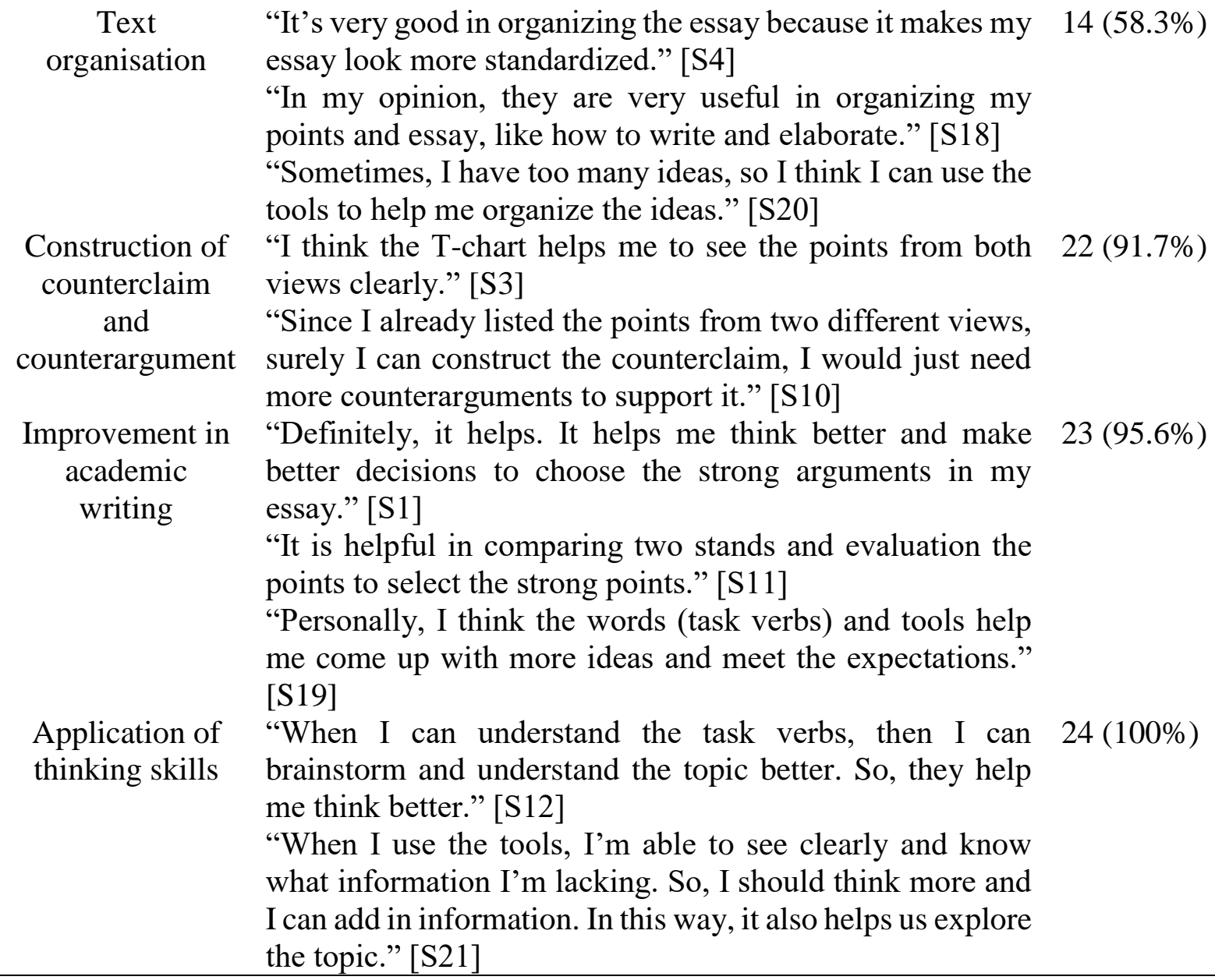

Text "It's very good in organizing the essay because it makes my $14(58.3 \%)$

Table 2 indicates the themes detected from the responses collected through the focus group discussions. These themes are in relevant with the students' perceptions on the effectiveness of the thinking skills framework in terms of academic writing aspects. All 24 participants (100\%) gave positive feedback in terms of the effectiveness of the TSF in the delivery of task instructions, topic exploration and the application of thinking skills throughout the writing process. First of all, the aim of using the TSF is to create clear educational outcomes for students to understand the task expectations and assist them in completing the tasks with specific instructions (Frangenheim, 2018).

From the responses, the clarity of the task verbs was highlighted by the participants that the task verbs are helpful because they are clear and specific. Meanwhile, they also provide "clear directions" and "clues" to help students understand the task nature. Besides, the participants also stated that the TSF tools such as mind maps, outlines and T-chart were useful in assisting them to explore the topics because they enabled them to see the connections between the points and further expand their ideas based on the connected points. Moreover, all participants agreed that using the TSF helped them apply the thinking skills, as in to help them "think better" when exploring the topic. One participant mentioned that he knew he should "think more" when he realized he was lacking some information in the writing draft created using the TSF tools. 
One of the themes identified from the participants' responses was the effectiveness of the TSF tools in the construction of counterclaim and counterarguments. Most of them $(91.7 \%)$ stated that when they used the TSF tools, particularly the T-chart, it was very helpful in clarifying the opposite points of view, as quoted "see the points from both views clearly". Another participant explained that the T-chart helped to list down the points, including the opposing points, so she had no problem in constructing the counterclaim.

Another notable finding is that many participants $(58.3 \%)$ asserted that the tools were very good and useful in organizing the text. Some situational examples were given to explain their opinions on using the tools. The participants agreed that the tools were useful in: (1) standardizing the text, (2) organizing the ideas such as selecting the stronger points when they had too many points, and (3) elaborating the points.

The experimental participants gave their opinion on the effectiveness of the TSF intervention in improving their overall academic writing skills. Almost all of them (95.6\%) agreed that the intervention was effective in upskilling their academic writing as it was claimed to be "helpful" in many writing aspects, such as making better writer decisions, idea evaluation skills and most importantly, meeting the writing expectations. Only one of them $(8.4 \%)$ denied the effectiveness of the TSF as the participant explained that the TSF was very new to her, thus it did not seem to be a good tool for the time being.

\section{Discussion}

The findings from the quasi-experiment indicate that the inclusion of the Frangenheim TSF in tertiary ESL classrooms has a great potential to upskill the students' academic writing competence. Besides, the findings from the focus group discussions indicate that students perceived the use of the Frangenheim TSF in upskilling academic writing as follow: TSF was able to improve their academic writing skills in terms of writing conventions and their ability to apply HOTS while completing the writing tasks. When it came to writing conventions, many students gave positive comments on the effectiveness of the TSF that the TSF assisted them mainly in several writing aspects, as shown in Table 2: (1) exploring the topic, (2) organizing the text and (3) constructing counterclaim and counterarguments. All these writing skills cannot be completed without the application of HOTS as all students $(100 \%)$ agreed that they were able to think better and deeper when they were using the TSF to help complete the writing task. This finding is in line with Ganapathy and Kaur's (2014) findings that using the TSF in writing is able to challenge the students to think critically and assist them in producing creative written text by motivating them to generate more ideas related to the topic.

The students claimed that the TSF was helpful especially when they needed to make decisions such as selecting the strong arguments to be included in the essay after evaluating the weightage of the points. According to Selvaraj and Aziz (2019), writer's mental processes are prioritized as these processes involve making the right decisions throughout the writing process in which it involves analyzing the topic-related claims, evaluating the arguments, synthesizing the gathered information and creating an organized text. Many students mentioned that they used T-chart to help compare and evaluate points before they made decisions. This finding indicate that students engaged themselves throughout the writing process, from generating ideas to selecting the strong 
ideas based on the information they have. This concurs with the claim made by Flower and Hayes's (1981) that learners take control over the writing process when they are given opportunities to make their writers' decisions and this is a set of mental processes that should be emphasized by the language teachers, rather than over focusing on the linguistic accuracy.

Another finding indicates that the TSF is an effective tool in setting educational outcomes as all participants (100\%) agreed that the task verbs were able to deliver the task instructions in a clear and specific way. Moreover, the task verbs allow the students to think better and understand the writing task expectations. This finding concurs with some of the findings presented in Korzh (2017) study in which the functions of the task verbs in the Bloom's Taxonomy were stated as follow: develop students' writing skills, set clear and realistic learning outcomes and presenting the tasks clearly based on different thinking skills.

In short, the findings of this study suggest that Frangenheim TSF facilitate tertiary students' development of writing skills and critical thinking skills which are deemed necessary to master the English language as the second language. Due to the recent shift of the educational aspirations set by the Ministry of Education, tertiary ESL teachers and students are recommended to place emphasis on not only the linguistic competency, but also HOTS in language teaching and learning.

Based on the positive findings, it is a viable option to use the TSF in the teaching of writing among other tertiary students. It is also suggested to examine the potential of TSF in other ESL writing contexts, especially in the teaching of writing at the primary level, provided that the materials and lesson plans are modified to the suitable level for the primary students.

\section{Conclusion}

In conclusion, the Frangenheim TSF bring positive effects on improving tertiary students' academic writing skills. A strategic framework is required to help tertiary students overcome the writing difficulties caused by the lack of writing strategies and insufficient thinking tools. In regards to the students' perceptions, students view Frangenhiem TSF as a useful and effective tool to upskill their academic writing as the framework is able to specify the task requirements, assist the students' thinking processes. It also functions as a writing tool to facilitate students' topic exploration, argument formation, idea evaluation and text organization. The students also stressed that the task verbs are able to specify the task nature and provide clear direction for them to meet the writing expectations.

The findings posit several implications which include developing independent tertiary learner by providing a potential writing and thinking tool, assisting tertiary teachers in setting educational outcomes for the teaching of ESL writing and giving insights to other tertiary educational stakeholders in developing ESL individuals who are both linguistically and intellectually competent. Since this TSF has been explored superficially, further studies are recommended to investigate the effectiveness of this TSF with a larger scale of sample and in other ESL contexts. 
Using Frangenheim's Thinking Skills

\section{References}

Abdulkareem, M. (2013). Investigation study of academic writing problems faced by Arab postgraduate students at Universiti Teknologi Malaysia (UTM). Theory and Practice in Language Studies, 3(9), 1552-1557.

Al_Sawalha, A. B. S. \& Chow, T. V. F. (2012). The effects of writing apprehension in English on the writing process of Jordanian EFL students at Yarmouk University. International Interdisciplinary Journal of Education, 1(1), 6-14. Retrieved from http://iijoe.org/v1/IIJE_02_v1_i1_2012.pdf

Al Badi, I. A. H. (2015). Academic writing difficulties of ESL learners. Paper presented at The 2015 WEI International Academic Conference Proceedings, Barcelona, 65-76. Retrieved from

https://www.westeastinstitute.com/wp-content/uploads/2015/02/Ibtisam-Ali-Hassan-AlBadi-full-Paper.pdf

Anderson, L. W., Krathwohl, D. R., Airasian, P. W., Cruikshank, K. A., Mayer, R. E., Pintrich, P. R., Raths, J., \& Wittrock, M. C. (2001). A taxonomy for learning, teaching, and assessing: A revision of Bloom's Taxonomy of educational objectives. New York: Longman.

Bloom, B. S., Engelhart, M. D., Furst, E. J., Hill, W. H., \& Krathwohl, D. R. (1956). Taxonomy of educational objectives: The classification of educational goals. New York: Longmans.

Creswell, J. W. (2014). Research design: Qualitative, quantitative, and mixed methods approaches ( $4^{\text {th }}$ ed.). Thousand Oaks, CA: SAGE Publications.

Flower, L., \& Hayes, J. R. (1981). A cognitive process theory of writing. College Composition and Communication, 32(4), 365-387. https://doi.org/10.2307/356600

Foster, D., \& Russell, D. R. (2002). Writing and learning in Cross-National Perspective. Transitions from secondary to higher education, Urbana, IL: National Council of Teachers of English.

Frangenheim, E. (2006). Thinking skills framework. Retrieved from http://www.itcpublications.com.

Frangenheim, E. (2018). Reflections on classroom thinking strategies $\left(1^{\text {st }}\right.$ ed.) [e-book]. Retrieved from http://books.google.com

Ganapathy, M., \& Kaur, S. (2014). ESL students' perceptions of the use of higher order thinking skills in English language writing. Advances in Language and Literary Studies, 5(5), 8087. https://doi.org/10.7575/aiac.alls.v.5n.5p.80

Ismail, N., Hussin, S., \& Darus, S. (2012). ESL tertiary students' writing problems and needs: Suggested elements for an additional online writing program (IQ-Write) for the BEL 311 course. The International Journal of Learning, 18(9), 69-80. https://doi.org/10.18848/1447-9494/CGP/v18i09/47748

Ismail, S. A. A. (2011). Exploring students' perceptions of ESL writing. English Language Teaching, 4(2), 73-83. https://doi.org/10.5539/elt.v4n2p73

JobStreet. Fresh Graduate Report 2018. Retrieved from https://www.jobstreet.com.my/announcement/FTP/FACT-SHEET_Fresh-GraduateSurvey-2018.pdf

Kirmizi, O., \& Kirmizi, G. D. (2015). An investigation of L2 learners' self-efficacy, writing anxiety and its causes at higher education in Turkey. International Journal of Higher Education, 4(2), 57-66. https://doi.org/10.5430/ijhe.v4n2p57 
Korzh, O. (2017). Bloom's Taxonomy and its role in academic writing and reading skills training at English classes. Science and Education, 2, 111-115. https://doi.org/10.24195/24144665-2017-2-18

Lau, S. M., \& Rahmat, N. (2014). English language writing anxiety among final year engineering undergraduates in Universiti Putra Malaysia. Advances in Language and Literacy Studies, 5(4), 102-106. https://doi.org/10.7575/aiac.alls.v.5n.4p.102

Ministry of Education Malaysia. (2015). Executive summary of Malaysia education blueprint 2015-2025 (Higher Education). Putrajaya, Malaysia: Author

Moseley, D., Elliott, J., Gregson, M., \& Higgins, S. (2005). Thinking skills frameworks for use in education and training. British Educational Research Journal, 31(3), 367-390. https://doi.org/10.1080/01411920500082219

Nevid, J. S., Ambrose, M. A., \& Pyun, Y. S. (2017). Effects of higher and lower level writing to writing-to-learn assignments on higher and lower level examination questions. Teaching of Psychology, 44(4), 324-329. https://doi.org/10.1177/0098628317727645

Özdemir, S. (2018). The effect of argumentative text pattern teaching on success of constituting argumentative text elements. World Journal of Education, 8(5), 112-122. https://doi.org/10.5430/wje.v8n5p112

Peng, S. (2019). A study of the differences between EFL and ESL for English classroom teaching in China. IRA International Journal of Education and Multidisciplinary Studies, 15(1), 3235. https://doi.org/10.21013/jems.v15.n1.p4

Putri, R. O. (2018). Investigating the link between critical thinking skills and argumentative writing skill: The case of Islamic senior high school. Jurnal Pendidikan dan Pengajaran, 5(2), 144-153. https://doi.org/10.19109/ejpp.v5i2.2090

Rahim, S. A., Jaganathan, P., \& Mahadi, T. S. T. (2016). An investigation on the effects of writing anxiety on readiness of writing among low proficiency undergraduates. International Journal of Language Education and Applied Linguistics, 5, 11-20. https://doi.org/10.15282/IJLEAL.V5.495

Selvaraj, M., \& Aziz, A. A. (2019). Systematic review: Approaches in teaching writing skill in ESL classrooms. International Journal of Academic Research in Progressive Education and Development, 8(4), 450-473. https://doi.org/10.6007/IJARPED/v8-i4/6564

Sham, D. P. L. (2016). Teaching and learning ESL writing by critical thinking. American Journal of Educational Research, 4(12), 854-860. https://doi.org/10.12691/education-4-12-1

Sun, F. (2014). The application of schema theory in teaching college English writing. Theory and Practice in Language Studies, 4(7), 1476-1482. https://doi.org/10.4304/tpls.4.7.1476-1482

Wang, H., \& Zou, Y. (2018). Advancing academic English teaching and learning in China: A meta-analysis. Journal of Language Teaching and Research, 9(6), 1260-1269. http://doi.org/10.17507/jltr.0906.15

Yasin, A. Y. M., Shaupil, W. M. H. W. M., Mukhtar, A. M., Ghani, N. I. A., \& Rashid, F. (2010). The English proficiency of civil engineering students at a Malaysian polytechnic. Asian Social Science, 6(6), 161-170. https://doi.org/10.5539/ASS.V6N6P161 